\title{
A TRIBOLÓGIAI JELLEMZŐK JAVÍTÁSA MÁGNESES POLÍROZÁSSAL ÉS FELÜLETHENGERLÉSSEL
}

\section{THE TRIBOLOGICAL PARAMETERS IMPROVED BY MAGNETIC POLISHING AND ROLLING}

\author{
Kodácsy János ${ }^{1}$, Kovács Zsolt Ferenc ${ }^{2}$ \\ ${ }^{I}$ Kecskeméti Föiskola, GAMF Kar, Jármütechnológia Tanszék. Cím: Magyarország, \\ H-6000 Kecskemét, Izsáki út 10; kodacsy.janos@gamf.kefo.hu \\ ${ }^{2}$ Kecskeméti Föiskola, GAMF Kar, Jármütechnológia Tanszék. Cím: Magyarország, \\ H-6000 Kecskemét, Izsáki út 10; kovacs.zsolt@gamf.kefo.hu
}

\begin{abstract}
In this publication the authors present the results of their research. During the research the fine turned and then grinded pre-machined surfaces were polished and rolled in the magnetic field as to examine the possibility of the combination of both technologies. The aim was to improve the tribological parameters of treated surface. C45 normalized steel was used as workpiece material which was machined different technological parameters. The evaluation was done by advanced measuring and IT equipment.
\end{abstract}

Keywords: magnetism, burnishing, polishing, finishing.

\section{Összefoglalás}

A szerzők a publikációban beszámolnak kutatómunkájuk eredményeiről. A kutatás során a finomesztergálással, majd köszörüléssel előzetesen megmunkált felületeket mágneses térben polírozták és hengerelték úgy, hogy a két technológia együttes alkalmazásának lehetőségét is vizsgálták. Céljuk az így kezelt felületek tribológiai tulajdonságainak javítása volt. A kísérlethez C45-ös, normalizált állapotú acélt használtak, és a megmunkáláshoz különböző technológiai paramétereket alkalmaztak. A kiértékelést korszerü mérőmüszerekkel és informatikai eszközökkel végezték.

Kulcsszavak: mágneses, hengerlés, polírozás, befejezés.

\section{Bevezetés}

A mágneses térrel segített technológiák világviszonylatban is újszerü fejlesztés alatt álló megmunkálási módok. Legfőbb jellemzőjük, hogy a megmunkáláshoz szükséges erőt a munkatérben létesített szabályozható vagy állandó nagyságú mágneses térerő biztosítja.[1]

Legelterjedtebben a polírozás területén alkalmazzák a mágneses erőt. A megmun- kált darab lehet hengeres, sík és alakos felület is. Mindegyik geometriának saját megmunkálási módja alakult ki, melyek közül némelyik további lehetőségeket is biztosít a felület megmunkálása terén.[2]

A mágneses erővel végzett eljárások hátránya, hogy hatékonyan polírozáskor kemény, hengerléskor lágyabb, mágnesezhető anyagok esetén lehet csak alkalmazni. 


\section{Mágneses finomfelületei techno- lógiák}

\subsection{Mágneses polírozás}

Külső hengeres felületek mágneses polírozásakor a két mágnes pólus és a munkadarab közt létesített stacionárius mágneses munkatérbe mágnesezhető csiszolószemcsét adagolnak (1. ábra). Ezzel az eljárással a felület érdessége átlagosan akár harmadáraötödére csökkenthetö. [1]
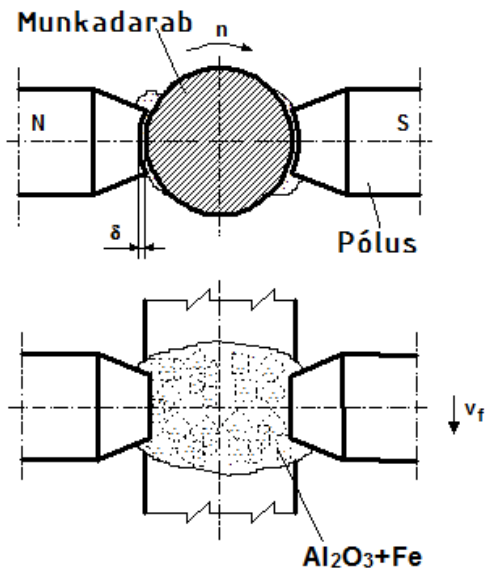

1. ábra. Mágneses polírozó berendezés [2]

\subsection{Mágneses felülethengerlés}

A felülethengerlés során a megmunkálandó anyagnál jóval keményebb golyó vagy gyürủ alakú szerszámot erővel a felületre nyomjuk és legördítjük. A hengerlés során Hertz-féle érintkezési feszültségek jönnek létre az anyag peremzónájában. Ha ez a feszültség nagyobb az anyag folyáshatáránál, akkor az anyag felszínéhez közel megkezdődik egy speciális ,anyagáramlás”. A plasztikusan deformálódott zóna felszíne a hengerlés hatására tömörödik, $\mathrm{s}$ a felületi kiemelkedések belefolynak a körülötte lévő „völgybe”. Mindez a felület érdességének javulását és felkeményedését eredményezi.[3]

A mágneses hengerlés során a szükséges felületalakító erő létrehozásához a mágneses erőt használjuk. A mágnesezéssel segített felülethengerlési megoldás jelentösége egyszerüségében és a hengerléshez szükséges erő lokalizálásában van, így elkerülhető a munkadarab káros vetemedése.

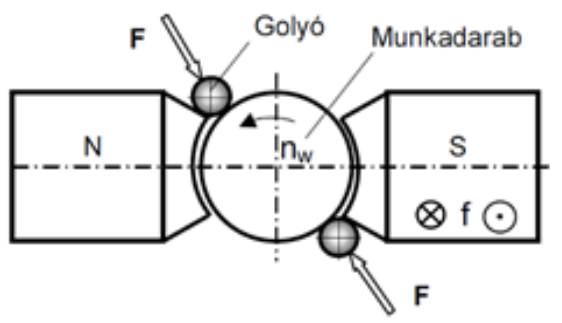

2. ábra. Mágneses hengerlö berendezés [2]

\section{Kísérleti körülmények}

A kísérleteket egy egyetemes csúcseszterga hossz szánjára adaptált, szabályozható erősségủ elektromágnessel végeztük. Hengerlésnél és polírozásnál is azonos áramerősséget (I=10A) és feszültséget $(\mathrm{U}=40 \mathrm{~V})$ alkalmaztunk, mert hengerlésnél a minél nagyobb hengerlőerő elérése a cél, míg polírozásnál számolnunk kellett az erö felületen történő megoszlásával is. Ez alapján az elektromágnessel létrehozott mágneses térerősség a $\delta$ résben üresen (golyó és polírozó por nélkül) $\mathrm{B}=0,96 \mathrm{~T}$ volt. $\mathrm{Ez}$ az érték behelyezett hengerlő golyók esetében nem változott, viszont polírozó szemcsék esetében lecsökkent $\mathrm{B}=0,75 \mathrm{~T}$ értékre. $\mathrm{A}$ mágneses térerő csökkenése az alkalmazott $\mathrm{Al} 2 \mathrm{O} 3+\mathrm{Fe}$ polírozó szemcsék árnyékoló tulajdonágának tudható be.

A pólus és a munkadarab közötti $\delta$-rés nagysága egységesen mindkét eljárásnál $3 \mathrm{~mm}$-re volt beállítva.

A kísérletekhez 2 darab $\varnothing 27,5 \times 400$ mm-es C45 jelü, normalizált állapotú szénacélt használtunk, melyet előzetesen finomesztergáltunk, majd köszörültünk.

A megmunkálásokat két csúcs között végeztük és a munkadarabot homlokmenesztő csúccsal forgattuk. 
A két technológia hasonló elven müködik, de mégis két különböző technológiáról kell beszélnünk. Ennek függvényében a technológiai paraméterek meghatározásakor a hengerlést különböző hengerlési sebességek (vb) és elötolások (fb) mellett végeztük, míg a polírozást az idő (tp) és polírozási sebességek (vp) változtatásával végeztük.

Technológiai paraméterek megválasztásakor felhasználtuk korábbi kísérleteknél alkalmazott értékeket, illetve az arra a technológiára jellemző paramétereket alkalmaztuk. Az így kialakult értékeket az 1. táblázat tartalmazza felülethengerlés és a 2. táblázat polírozás esetén.

1. táblázat. Hengerlési paraméterek

\begin{tabular}{|c|c|c|c|}
\hline $\begin{array}{c}\text { Felület } \\
\text { jele }\end{array}$ & $\begin{array}{c}n_{w} \\
(1 / \mathrm{min})\end{array}$ & $\begin{array}{c}\mathrm{v}_{\mathrm{b}} \\
(\mathrm{m} / \mathrm{min}) \\
\end{array}$ & $\begin{array}{c}\mathbf{f}_{\mathbf{b}} \\
(\mathrm{mm} / \text { ford })\end{array}$ \\
\hline $1 \mathrm{r}$ & 265 & 23 & \multirow{3}{*}{0,05} \\
\hline $2 r$ & 375 & 32 & \\
\hline $3 r$ & 750 & 65 & \\
\hline $4 \mathrm{r}$ & 265 & 23 & \multirow{3}{*}{0,1} \\
\hline $5 r$ & 375 & 32 & \\
\hline $6 r$ & 750 & 65 & \\
\hline $7 \mathrm{r}$ & 265 & 23 & \multirow{3}{*}{0,2} \\
\hline $8 \mathrm{r}$ & 375 & 32 & \\
\hline $9 \mathrm{r}$ & 750 & 65 & \\
\hline
\end{tabular}

2. táblázat. Polírozási paraméterek

\begin{tabular}{|c|c|c|c|}
\hline $\begin{array}{c}\text { Felület } \\
\text { jele }\end{array}$ & $\begin{array}{c}n_{w} \\
(1 / \mathrm{min})\end{array}$ & $\begin{array}{c}\mathbf{v}_{\mathbf{p}} \\
(\mathbf{m} / \mathbf{m i n}) \\
\end{array}$ & $\begin{array}{c}\mathbf{t}_{\mathrm{p}} \\
\text { (min) }\end{array}$ \\
\hline $1 p$ & 265 & 23 & \multirow{3}{*}{1} \\
\hline $2 p$ & 750 & 65 & \\
\hline $3 p$ & 1060 & 92 & \\
\hline $4 p$ & 265 & 23 & \multirow{3}{*}{2} \\
\hline $5 p$ & 750 & 65 & \\
\hline $6 p$ & 1060 & 92 & \\
\hline $7 p$ & 265 & 23 & 3 \\
\hline $8 p$ & 750 & 65 & \multirow{2}{*}{0,5} \\
\hline $9 p$ & 1060 & 92 & \\
\hline
\end{tabular}

A hengerlést és a polírozást is különkülön munkadarabon (1-es és 2-es tengely) végeztük el. Az így kapott különböző technológiai paraméterekkel hengerelt és polírozott munkadarabok felületi jellemzőit megmértük, s a két, általunk mért legjobbnak vélt felületen alkalmazott technológiai adatokat használva políroztuk a hengerelt felületeket, illetve hengereltük a polírozott felületeket.

\section{Kiértékelés}

A méréshez MITUTOYO Formtracer SV-C3000 típusú érdességméröt, a kiértékeléshez Excel adatkezelöt használtunk. Minden megmunkált felületen három mérést végeztünk el, melyeknek átlagértékeivel végeztük a kiértékelést.

\subsection{Az átlagos felületi érdesség alaku- lása}

A mért Ra értékeket a 3. ábra tartalmazza, ahol a müveletek neve mellett zárójelben a tengely száma is fel van tüntetve.

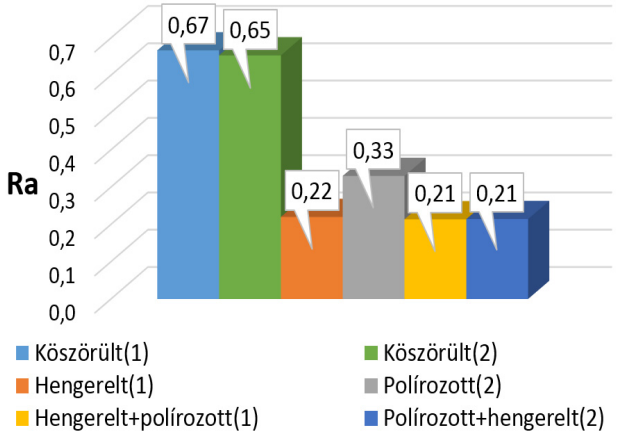

3. ábra. Az egyes MAM technológiák Ra értékei

A kapott Ra értékek a vártaknak megfelelően alakultak. A csúszó felületek érdességi értékei nagyban befolyásolják az egymáson való elmozdulást, de az Ra eredmények nem jellemzik megfelelöen a csúszó felületek (pl. csúszó vezeték és szán) müködés közbeni viselkedését. Ezen tulajdonságok meghatározására az úgynevezett ferdeségi (Rsk) és kurtosis (Rku) paraméterek alkalmasak. A továbbiakban azt vizsgáltuk, hogy az elöbbi két felületi jellemző, hogyan alakul a technológia és a technológiai paraméterek változtatásával és kombinálásával. 


\subsection{Az Rsk és az Rku alakulása}

A szakirodalomból rendelkezésünkre állt egy összefoglaló Rsk - Rku topológiai térkép, ami tartalmazza különböző megmunkálásokkal kapott felületek értékeit (4. ábra). A diagramon jól látható, hogy a különböző felületek csoportokat alkotnak. Ezen csoportok között szándékozzuk elhelyezni a MAM (Magnetic Assisted Machining) technológiákat.

A topológiai térképen szereplő pontok akkor tekinthetők jónak, ha azok baloldalt és lent helyezkednek el.[4]

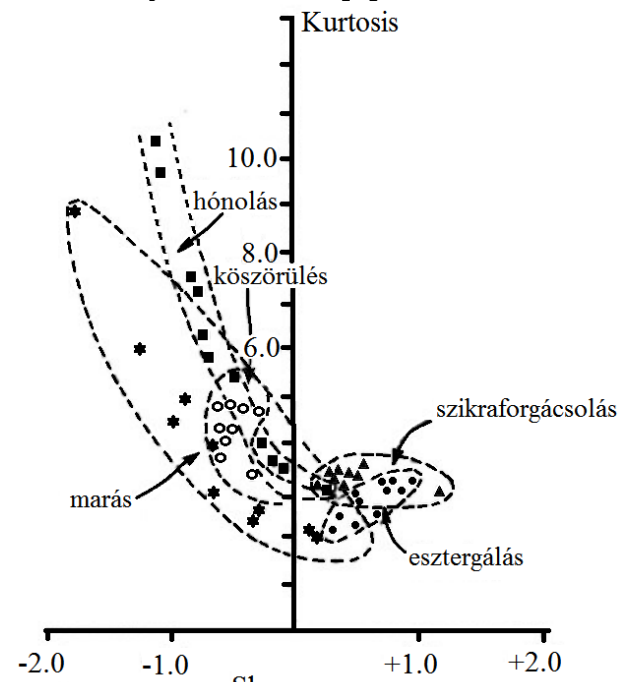

4. ábra. Különbözö eljárások Rsk - Rku topológiai térképe [4]

Az MAM technológiákkal kapott topológiai térképet az 5. ábra tartalmazza, melyen szembetűnő, hogy az egyes technológiák értékei szórnak, vagy éppen összetartanak. Észrevehető a 4. ábra és 5. ábra összevetéséből, hogy a MAM technológiák a finomfelületi technológiák tartományába esnek. Különös képen a polírozással létrehozott felületek. Ha a felület Ra érdességét és az Rsk - Rku topológiai térképet veszszük, akkor tribológiai szempontból polírozott+hengerelt felület tekinthetö a legkedvezőbbnek.

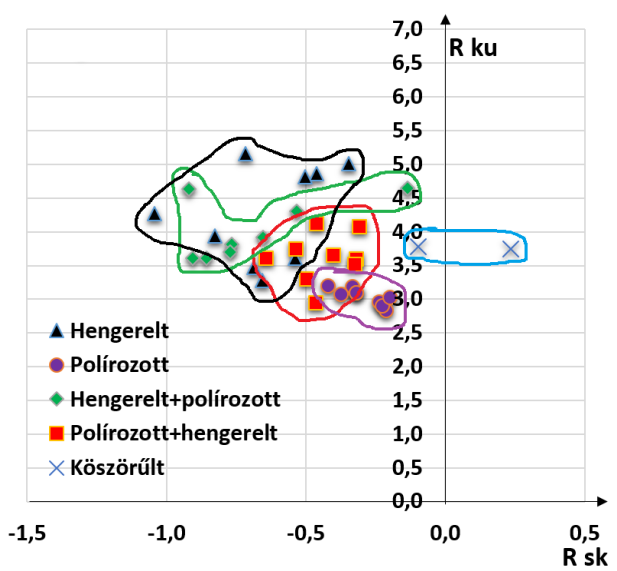

5. ábra. MAM technológiával gyártott felületek topológiai térképe

\section{Következtetések és további fe- ladatok}

A kísérletek eredményei alapján megalapítottuk, hogy a müködő felületek megmunkálására a megfelelö MAM technológia alkalmazása tribológiai szempontból pozitívan hat.

Célul tüztük ki, hogy a polírozásithengerlési MAM technológiát tovább vizsgáljuk a technológiai paraméterek optimálása, és a technológiák egy időben történő alkalmazása szempontjából.

\section{Szakirodalmi hivatkozások}

[1] J. Kodacsy, J. Danyi, A. Szabo, Gy. Fulop: Magnetic Aided Roller Burnishing Metal Parts. 7th International Conference on Deburring and Surface Finishing, UC Berkeley (USA), 2004, 375-378

[2] Kodácsy János, Líska János: Magnetic Assisted Roller Burnishing and Deburring of Flat Metal Surfaces. Advanced Materials Research Vol. TransTech 472-475 Publication Ltd, Zürich, 2012, 908-911.

[3] Kovács Zsolt: Mágneses felülethengerlési technológia fejlesztése (diplomaterv). BME, Budapest, 2015, 2-15.

[4] Whitehouse, D.J.: Handbook of surface metrology, Institute of Physics Bristol, UK, 1994. 